\title{
Dansk gymnastiks europæiske dimension
}

\author{
Af Roland Naul
}

\section{Introduktion}

»Hvad er det, der er så dansk ved danskerne?« er et spørgsmål, som Else Trangbæk for nylig stillede med henblik på at undersøge dansk gymnastiks nationale rødder. ${ }^{1}$ Hun har lige som så mange af sine velkendte danske kolleger inden for gymnastik, sport og kropskulturhistorie (f.eks. Korsgaard, Bonde, Copsø, Hansen, Lhyne, Kayser Nielsen, ${ }^{2}$ og sidst men ikke mindst Henning Eichberg) bidraget væsentligt til udforskningen og dokumentationen af den danske linie i den europæiske gymnastikog sportsbevægelse. ${ }^{3}$

Som en trænet fodboldspiller ville det være langt nemmere for mig at besvare spørgsmålet: »hvad er det, der er så specielt dansk ved dansk fodbold? «, idet jeg husker jeres landsholds gode præstationer ved det sidste verdensmesterskab i fodbold i Frankrig for nogle få uger siden. Under analysen af den europæiske dimension, inden for dette emne, kunne jeg selvfølgelig undlade ethvert tysk aspekt, hvis det $\varnothing$ nskes?

Angående dansk gymnastik i fortiden er det derfor meget mere behageligt for mig at se på det tyske aspekt af den europæiske dimension i dansk gymnastik. Svaret på spørgsmålet, »hvad er specielt dansk ved dansk gymnastik?«, må jeg imidlertid overlade til mine danske kolleger, som har adgang til jeres nationale historiske arki- ver, og som i modsætning til mig kan tale dansk og læse danske kilder.

Ikke desto mindre vil jeg i min artikel prøve at udpege, hvad der ser ud til at være en europæisk påvirkning af dansk gymnastik, samt den senere danske påvirkning af udviklingen inden for den europæiske gymnastikundervisning.

Først vil jeg se på den europæiske påvirkning af Danmark. Nogle påvirkninger blev mere eller mindre inkorporeret $\mathrm{i}$ skole- og fritidsundervisningen i gymnastik frem til 1898. På det tidspunkt påbegyndtes i København de et-årige kurser for gymnastiklærere, hvis 100 års jubilæum vi er her for at fejre.

For det andet vil jeg omtale eksporten fra Danmark. Hvad blev opfattet som dansk gymnastik ud fra et europæisk perspektiv? Hvordan blev det anvendt - hovedsageligt i engelsk og tysk skolegymnastikundervisning - efter 1904, da K. A. Knudsen blev udpeget til statsinspektør i gymnastik i de danske skoler?

\section{København: den forste europaiske skillevej inden for gymnastikken}

Da Johann Friedrich Gutsmuth, på sin filantropiske kostskole beliggende i Schnepfental (tæt ved den tyske by Weimar), i 1793 publicerede sin berømte bog med tit- 
len »Gymnastik for ungdommen«, dedicerede han bogen til Hans Majestæt Kronprins Frederik af Danmark. Kronprins Frederik, gik som andre drenge fra europæiske aristokratiske familier, på den velkendte kostskole i Schnepfental, hvor han selv deltog i J.C.F. Gutsmuths gymnastiktimer. Men hvorfor dedicerede Gutsmuths sin bog til den danske kronprins? Gutsmuths, på sin tid en berømt geograf, anerkendte Kronprins Frederik som »vogteren af menneskerettigheder ved bæltet og i Senegal $\ll,{ }^{4}$ fordi Danmark var den første kolonimagt i Europa, der forbød slaveri.

Omkring 20 kopier af Gutsmuths bog blev erhvervet af danskere, blandt dem Hendes Majestæt Prinsesse Louise, en general Firks og nogle andre danskere også uden for København. På grund af denne tidlige tysk-danske forbindelse er det ikke overraskende, at en københavnsk student, Franz Nachtegall, ${ }^{5}$ som var interesseret i fysiske aktiviteter og geografi, fik fingre i Gutsmuths bog. Nachtegall var afgjort imponeret af Gutsmuths fremhævelse af gymnastiske øvelser, og han åbnede selv et privat gymnastikinstitut i København i 1799. Ved slutningen af det 18. århundrede var København et kulturelt center for Norden, lige som Paris var det for Centraleuropa. Den franske revolutions intellektuelle ånd, kombineret med en vision om nordisk kultur og identitet, tiltrak studenter til København, blandt dem en poesi-interesseret svensker, Per Henrik Ling, som forlod Lund til fordel for København. Den 22 årige dansker Nachtegall og den 23 årige svensker Ling mødtes i Nachtegall's udendørs gymnastikinstitut under udøvelsen af tysk-inspirerede gymnastiske $\varnothing$ velser.

Fra de 5 studenter som Nachtegall underviste i 1799, steg antallet til 150 i slutningen af $1803 .{ }^{6}$ Førende repræsentanter for borgerskabet og officerer støttede
Nachtegall. Da den danske konge etablerede hærens første træningsskole for gymnastik i København i 1804, var den den første af sin art i Europa. Nachtegall blev skolens første leder. Samme år færdiggjorde Per Henrik Ling sine studier i København og vendte tilbage til Lund, hvor han begyndte at bygge videre på, hvad han havde lært af Nachtegall. Resten af Linghistorien, og hvad han senere udviklede $\mathrm{i}$ Sverige, er velkendt. ${ }^{7}$

I Tyskland var Nachtegall og hans venners arbejde velkendt. I forordet til anden udgave af sin bog »Gymnastik for ungdommen« udgivet i 1804 fremhæver Gutsmuths selv de fremskridt, der var blevet gjort i Danmark, samtidig med at han vemodigt spørger om, hvorfor intet tilsvarende var blevet opnået i de tyske stater. ${ }^{8}$

I København fortsatte Nachtegall som den førende inden for det offentliges gymnastikundervisning: Med henblik på at uddanne folkeskolelærere i faget gymnastik, som i 1814 skulle blive et obligatorisk fag i den danske grundskole, åbnedes i 1808 en civil afdeling af militærets gymnastiktræningsskole. I 1814 blev den civile afdeling lukket; men i løbet af disse 6 år uddeltes diplomer til 31 lærerstuderende, som herefter begyndte at indføre gymnastiske $\emptyset$ velser på seminarier over hele landet. ${ }^{9}$ I 1818 blev gymnastik et obligatorisk fag på de seminarier, som senere også blev superviseret af Nachtegall.

Indtil sidst i 1820 'erne forårsagede den politiske og $\varnothing$ konomiske depression i postNapoleon-tiden en forsinkelse i den videre udbredelse af gymnastik i de danske skoler. I henhold til en anden af Nachtegalls gymnastikinstrukser, der blev godkendt af Kong Frederik den 6., blev gymnastik ved lov gjort obligatorisk i danske mellem- og kommuneskoler i 1828.

Ved slutningen af 1830erne blev det an- 
slået, at næsten 2000 grundskoler i Danmark gav gymnastikundervisning, mens det rapporteredes, at mere end $90 \%$ af gymnasieskolerne gav samme tilbud. ${ }^{10}$ Med Kong Frederik den 6. død i 1839 og Nachtegalls pensionering i 1842 sluttede den første epoke af statsstøttet og statspromoveret gymnastikundervisning.

En af de bedste historikere, hvad angår gymnastikundervisning, amerikaneren Fred Leonard, der selv boede i København omkring slutningen af det 19. århundrede, vurderede perioden således: Det er hans (Nachtegall's) fortjeneste, at Danmark i de første tre fjerdedele af det 19. århundrede var førende blandt de europæiske nationer, hvad angår gymnastikundervisningen. ${ }^{11}$

Jeg mener, at Leonard har ret, specielt hvis vi sammenligner den danske indførelse af gymnastik i læreruddannelsen på militære og civile skoler med lignende bestræbelser i andre europæiske lande.

Sammenlignet med andre europæiske lande var Danmark faktisk ret langt foran, hvad angår udbredelsen af gymnastikundervisning i skoler.
Dette resultat kan også underbygges ved at sammenligne årstal for, hvornår gymnastik i grund- og mellemskole blev obligatorisk ved lov i andre lande end Danmark. ${ }^{12}$

København var helt klart den første milepæl i den europæiske gymnastikundervisning. J.C.F. Gutsmuths samling af »educational gymnastics « var utvivlsomt grundlaget for udviklingen af den gymnastikundervisning, der blev brugt af Nachtegall og Ling. Men Frans Nachtegall brugte ikke kun Gutsmuths samling, som i hans bog starter med »spring «. Ifølge Else Trangbæk, lancerede Nachtegall i sine forskellige danske instrukser for skolegymnastikundervisning også nogle spring- og akrobatikøvelser, der ikke var opført hos Gutsmuths. ${ }^{13}$ Et tidligt nationalt dansk element må derfor ikke overses. Akrobatiske $\emptyset$ velser var selvfølgelig kendt over hele Europa på det tidspunkt; men de var fuldstændig udeladt fra skolegymnastikundervisningen med Danmark som eneste undtagelse.

Tabel 1: Starttidspunkter for gymnastikundervisningen på militcere skoler og seminarier

\begin{tabular}{lll}
\hline & Militære skoler & Seminarier \\
\hline B & 1866 & 1854 \\
D & 1847 & 1827 \\
& $(1851)$ & \\
DK & 1804 & 1818 \\
F & 1817 & 1887 \\
& $(1852)$ & \\
GB & 1822 & 1840 \\
& $(1862)$ & \\
GR & 1892 & 1834 \\
I & 1833 & 1861 \\
N & 1870 & 1869 \\
NL & 1814 & 1851 \\
& & $(1881)$ \\
\hline
\end{tabular}


Tabel 2: Arstal for indførelse af gymnastik som obligatorisk fag i europæiske skoler

\begin{tabular}{llll}
\hline & Grundskole & Mellemskole & Gymnasieskoler \\
\hline B & 1879 & 1850 & 1842 \\
D & 1847 & & 1860 \\
DK & 1814 & 1828 & 1828 \\
F & 1880 & 1868 & 1868 \\
GB & 1944 & & 1902 \\
I & 1878 & 1862 & 1859 \\
L & 1861 & 1872 & 1888 \\
N & 1879 & 1869 & 1869 \\
NL & 1889 & 1863 & 1879 \\
\hline
\end{tabular}

Den danske identitets vakst: promovering af gymnastik $i$ skytteforeninger og højskoler

Grundtvigs ideer og højskoleånden var allerede ved at brede sig i 1840'erne. Den første højskole blev grundlagt ved Rødding i 1844. Inspireret af Kaptajn Mønster blev frivillige skytteforeninger grundlagt $\mathrm{i}$ 1861. På bare 2 år oprettedes over et hundrede foreninger inden den tysk-danske krig begyndte i 1864. Tabet af Schleswig, Holstein og Lauenburg, som et resultat af krigen, forcerede den danske nationalbevægelse og førte til en hurtig spredning af oprettelsen af skytteforeninger og højskoler.

Allerede før krigen blev gymnastik, som fremelskede militær eksercits, føjet til skytteforeningernes aktiviteter, men disse aktiviteter modtog senere yderligere støtte. I 1872 udførte 11 skytteforeninger, med mere end 2000 medlemmer, gymnastik på regelmæssig basis. Det første gymnastikhus, meget lig en gymnastiksal, blev åbnet ved Ryslinge på Fyn i 1871. Omkring 300 af sådanne huse blev bygget af skytteforeningsmedlemmer og tilhængere af højskolebevægelsen. ${ }^{14}$ Medlemmer af skytteforeningerne udførte elementer af Jahns øvel- ser og også dele af det nye Spiess-system, som fokuserede på orden og marchøvelser. Den tyske militærånd i gymnastikken var ikke synlig i højskolebevægelsen, hvor gymnastiske øvelser med Gutsmuths og Nachtegall som baggrund blot spillede en mindre rolle. Der var imidlertid bånd imellem begge nationale bevægelser, som når skytteforeninger søgte gruppeledere og gymnastikinstruktører til kurser organiseret i aulaerne på højskolerne. Askov- og Vallekilde højskoler har siden 1878 åbnet deres døre for sådanne korterevarende kurser i gymnastik.

Selv om formålet med at træne unge danskeres nationale identitet v.h.a. gymnastik var meget imod, hvad man opfattede som germanisering, ${ }^{15}$ forekommer det mig, at der indtil 1880'erne i begge nationale bevægelser, men især i skytteforeningerne, var et element af gymnastikeksercits lånt fra tyske kilder. Det forekommer mig derfor logisk, at et nordisk gymnastiksystem blev introduceret på instruktørkurser på Vallekilde Højskole i 1884, da N.H. Rasmussen bød velkommen til det første svenske hold, som demonstrerede Ling-systemet i den nye Vallekilde gymnastiksal.

Den nordiske ånd, som er indeholdt $\mathrm{i}$ Ling systemet, er i overensstemmelse med 
ånden i den danske nationale identitet, som både højskoler og skytteforeningsbevægelsen har stræbt efter siden den tabte krig i 1864.

\section{Udviklingen af et dansk gymnastiksystem: svensk assimilation, engelsk indflydelse og dansk-tyske levn}

Den paramilitære ånd, symboliseret ved at der inden for skytteforeningsbevægelsen suppleredes med gymnastikeksercits og frie øvelser, nåede også til skolegården i de danske gymnasieskoler. I 1873 foreskrev et nyt cirkulære, der blev udsendt efter vedtagelsen af gymnasieuddannelsesloven af 1871, at der skulle være fire gymnastiktimer om ugen og ikke mere end 30 elever i hver klasse. I 1870'erne og 1880'erne blev den traditionelle samling af Gutsmuths og Nachtegall's gymnastikøvelser for danske gymnasieskoler suppleret med nogle eksercits- og frie øvelser, idet man inddrog elementer af det tyske Spiesssystem blandt andet Jägers træ-og jernstokøvelser. ${ }^{16}$

Men sammenlignet med de militærlignende eksercitsøvelserne i tyske, franske og endda svenske gymnasieskoler, forblev militariseringen af skolegymnastikken i Danmark mindre udtalt på dette tidspunkt. ${ }^{17}$ Skolegymnastikundervisningen i Danmark var også under pres fra andre sider.

I 1881 offentliggjorde lægen Dr. Axel Hertel en bog med titlen Om Sundhedsforholdene i de højere Drenge- og Pigeskoler i Kjøbenhavn, hvor han kritiserede forholdene og manglen på hygiejne på skolerne. Kvantitative og kvalitative forbedringer af gymnastikundervisningen blev anbefalet. Det sidste blev kædet sammen med den britiske model for atletik og sport på kost- skoler. Tre år senere støttede en statsudpeget kommission Hertels kritik. I de tidlige 1880'ere var det traditionelle curriculum i dansk skolegymnastik imidlertid under større pres fra udbredelsen af den svenske import, Ling gymnastik.

Den landlige liberalt orienterede $h ø j$ skolebevægelse fik mere politisk indflydelse i byområderne..$^{18}$ I København og andre byer tiltrak deres stræben efter nordiske værdier, udtrykt ved skiftet til nordisk gymnastik, liberale politikere og moderne lærere. Traditionel tysk-dansk gymnastik blev forsvaret af repræsentanter for borgerskabet og officerer fra hæren, som Kaptajn J. Amsinck, mens læger og svenskuddannede folkegymnaster som N.H. Rasmussen $\emptyset$ nskede at erstatte tysk-inspireret skolegymnastik med Ling-systemet.

Skønt Kirke- og Undervisningsministeriet i 1887 udpegede en kommission bestående af J. Amsinck, Dr. Hertel og Prof. Kroman, var der i midten af 1880 'erne en gymnastikfejde i Danmark, ${ }^{19}$ lige som der var i Tyskland omkring 1860 og i Belgien i 1870 'erne. Kommissionen med forskellige synspunkter og indstillinger besøgte det Kongelige Centrale Gymnastikinstitut i Stockholm samt Berlins Gymnastiklærerhøjskole, hvor Carl Euler var rektor. ${ }^{20}$ I deres rapport til ministeriet anbefalede holdet bedre organisering af gymnastiktimerne og forbedring af læreruddannelsen. De foreslog også at lave en ny håndbog i skolegymnastikundervisning, som skulle udformes af en udvidet ekspertgruppe.

I $1889 \mathrm{blev}$ en større forsamling udpeget, og denne inkluderede nu flere stærke danske Ling-tilhængere som N.H. Rasmussen. Denne gruppes arbejde blev offentliggjort 10 år senere, en publikation på mere end 500 sider der må betragtes som en idrætslig milepæl: den berømte Håndbog for gymnastik (Gymnastikhåndbog) 
fra 1899. Dette store værk skulle blive den danske ledetråd for skolegymnastik, og for den nye danske civile gymnastiklæreruddannelse, som allerede var begyndt på N.H. Rasmussen's gymnastikinstitut 1 . september 1898.

Hvis vi ser på elementerne i dette danske gymnastiksystem, så benytter det sig af Ling-systemet blandet med ånden fra almue- og engelske lege, og samtidigt værnende om de traditionelle danske spring $\varnothing$ velser og nogle tyske frie $\varnothing$ velser og redskabsøvelser. ${ }^{21}$

Men hvordan var hverdagen i de danske gymnasieskoler i 1880'- og 1890'erne frem til offentliggørelsen af håndbogen som den nye manual for gymnastikundervisning?

Henrik Meinander analyserede gymnastikundervisningen, som blev givet af lærere på Metropolitanskolen, Frederiksberg Latin- og Realskole og Østre Borgerdydskole i København. ${ }^{22}$ If $ø$ lge Meinander, var der ved århundredeskiftet ikke nogen indflydelse på den almindelige gymnastikundervisning i gymnasieskolerne fra Linggymnastikken. I stedet for var engelsk atletik og spil, som fodbold og endda cricket, blevet introduceret som fritidsaktiviteter. Almindelige gymnastiktimer fokuserede stadig på Gutsmuths' og traditionelle danske $\varnothing$ velser med tyske eksercits- og redskabsøvelser. ${ }^{23}$

I 1904 blev K.A. Knudsen udnævnt til gymnastikinspektør, som den første civile efter Nachtegall, og selvom han kraftigt promoverede udbygningen af Ling-gymnastik i praktisk undervisning i gymnasieskolerne, forblev gymnastiktimer sjældne frem til 1920erne. ${ }^{24}$

Uanset de forskellige opfattelser af om den Ling'ske gymnastik dominerede dansk gymnastik eller ej frem til slutningen af det
19. århundrede, ${ }^{25}$ så er det en kendsgerning, at K.A. Knudsen indledte den epoke, hvor dansk gymnastik blev attraktiv for lærere og uddannere i andre europæiske lande.

Vendepunktet, hvor importen af ideer og gymnastiksystemer fra Europa til Danmark ændredes til, at Danmark eksporterede ideer, gymnastikøvelser og undervisningsmetoder til andre europæiske lande, ser ud til at være tæt knyttet til K.A. Knudsens udnævnelse i 1904.

\section{Den tidlige eksport af dansk gymnastik til England}

Medens K.A. Knudsen i 1905 i et år besad embedet som statens gymnastikinspektør, rejste han til England for at afholde et feriekursus i dansk gymnastik for lærere ved Scarborough. Han fortsatte i 1906 og 1907, og lige fra begyndelsen blev han assisteret af to af sine tidligere elever, Junker og Langkilde, som tidligere havde bestået det nye et-årige gymnastikkursus i København. ${ }^{26}$ Både Junker og Langkilde underviste også engelske lærere i dansk gymnastik ved skolerne i West Riding, Yorkshire. Det engelske Krigsministerium ansatte Langkilde til at introducere den danske form for Ling-gymnastik ved Aldershot. Siden 1862 havde Aldershot været den britiske hærs træningsskole, hvor gymnastik og eksercits var blevet en vigtig del af officersuddannelsen. Men også andre af Knudsens elever, som Braae-Hansen og Brandt arbejdede som instruktører ved Southwestern Polytechnic Institute i London i 1908 og 1909, for at gøre kvindelige og mandlige gymnastiklærere bekendte med den danske måde at undervise i gymnastik. ${ }^{27} \mathrm{Da}$ K.A. Knudsen i 1908 holdt op med at undervise på feriekurser i England, bad han Junker 
om at fortsætte kursusvirksomheden alene. Samme år organiserede Junker for første gang et kursus for engelske lærere ved Silkeborg Gymnastik Institut i Danmark. I alt 32 skoleinspektører, rektorer og lærere fra England deltog i det første Silkeborg-kursus. Siden da underviste Junker i mange år på sommerferiekurser i Silkeborg og vinterferiekurser i England. Siden 1919 har Silkeborg Instituttet været velkendt i England under navnet Junker's Gymnastik Institut. ${ }^{28}$ Samme år tilbød Junker også et etårigt træningskursus for studenter. Undervisning i teori og praksis blev givet på engelsk, men ikke kun engelske studenter deltog i Junker's et-årige træningskursus. Studenterne kom fra hele Europa og oversøiske lande: Skotland, Irland, Holland, Tyskland og fra lande $\mathrm{i}$ det britiske imperium: Canada, Australien, New Zealand, Indien.

Nogle af de mere end 300 engelske studenter ved Junkers Institut fik senere stor indflydelse i deres hjemland, ved Aldershot, Carnegie College ved Leeds og inden for den engelske Ling-forening. ${ }^{29}$

Men det nyligt iværksatte gymnastiklærerkursus i København af 1898 blev også yderst attraktivt for studenter fra udlandet. Iflg. Leonard, bestod 15 internationale studenter eksamen frem til 1911. De kom fra Norge, Finland, Polen, Tyskland, Schweiz, Holland, England og Amerika. ${ }^{30}$

Efter århundredeskiftet tiltrak dansk gymnastik og gymnastiklærerundervisning, som vi har set, ikke kun engelske kvinder og mænd, men også andre europæiske studenter og lærere.

Foruden den tidlige eksport til England fik dansk gymnastik nogle år senere også stor indflydelse på skolegymnastikområdet specielt i Østrig, Schweiz og Tyskland. Men før dette blev en finsk dame og hendes mere individuelle, flydende og harmo- niske undervisning i svenske $\emptyset$ velser populær i Danmark. Det drejer sig om Elli Björksten. ${ }^{31}$ Uden hendes indflydelse på dansk gymnastik efter 1910, ville Niels Bukh sandsynligvis ikke være blevet så succesfuld, som han senere blev i Europa og andre steder.

\section{Indførelsen af dansk gymnastik i tysk skolegymnastik}

I 1899, da Håndbogen i Gymnastik blev publiceret i København, opholdt den berømte tyske læge Ferdinand August Schmidt sig i et par uger på Det Kongelige Centrale Gymnastik Institut i Stockholm. Schmidt evaluerede også undervisningen af Ling gymnastik på Stockholms folkeskoler. I hans mange artikler, og i hans bog om denne studietur, anbefalede han fra et fysiologisk synspunkt en samling af svenske gymnastikøvelser, specielt holdnings$\emptyset$ velser som supplement til den tyske gymnastikinstruktion i skolerne. ${ }^{32}$ Efter 1905 , under »Konferencen for undervisere af kunst« foreslog nogle innovative tyske gymnaster, udfra en mere æstetisk intention, at bruge svenske $\varnothing$ velser. ${ }^{33}$

En første akademisk diskussion om nordisk gymnastik begyndte i 1907 under en konference for den tyske gymnastiklærerforening i byen Stettin. Nogle værdifulde aspekter som F.A. Schmidt tidligere anbefalede blev ikke overset, men der kom kritiske bemærkninger om de små mængder af Ling'ske øvelser sammenlignet med mangfoldigheden af tyske gymnastiske $\emptyset$ velser og disses mangel på karakterudvikling, når man fokuserede på formningen af kroppen. $^{34}$

L. Törngren's bog om svensk gymnastik blev offentliggjort i Tyskland i $1908 .{ }^{35}$ Kun et år senere var der i et nyt gymnastikcir- 
kulære for prøjsiske folkeskoler, uden adgang til gymnastiksale, inkluderet svenske holdningsøvelser til brug ved almindelig undervisning. ${ }^{36}$ Rektorer og gymnastiklærere fra byerne Hamburg og Kiel rejste til København og andre steder i Danmark for at blive informeret om nye danske udviklinger, og om hvordan man underviste i gymnastik i danske skoler. Men før første verdenskrig var der kun lidt akademisk diskussion om fornyelsen af gymnastikundervisningen i Tyskland, jvf. L. Törngren og K.A. Knudsen. K.A. Knudsens bog om »Gymnastikøvelser« blev først udgivet i Tyskland i juli 1915. ${ }^{37}$

Efter 1920 begyndte i Østrig og Tyskland en ny epoke med bred modtagelse og inkorporering af dansk gymnastik i og uden for skolen.

\section{Curneriliche übungslehre}

pon K. B. Knudien

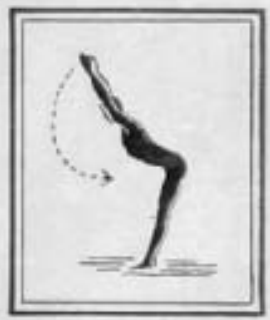

Derlag pon B. G. Teubner in trelpzlg
Den svage tendens i Tyskland, før første verdenskrig, til at reformere Spiessgymnastikken med nordisk gymnastik blev forstærket i de tidlige år af Weimarrepublikken, hjulpet og støttet af de mange forandringer i samfundet, den politiske orden og undervisningssystemet. I 1922 blev den fremtidige hjørnesten, i reformen af tysk skolegymnastik, offentliggjort i Wien af Karl Gaulhofer og Margrethe Streicher, senere kaldet grundlæggerne af den østrigske skole for naturlig gymnastik. ${ }^{38}$

Efter 2 år offentliggjordes anden reviderede udgave af bogen, hvori man refererede til de litterære kilder, som begge forfattere havde brugt før. De inkluderede for første gang også nogle billeder for at illustrere, hvad de mente med den grundlæggende

\section{Grundgymnaitik}

Deit

Tilels Bukh

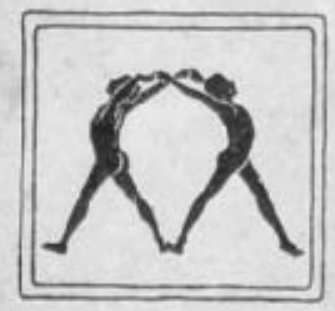

Lelpzig - Verlag voul B. G. Ceubner Berlin 


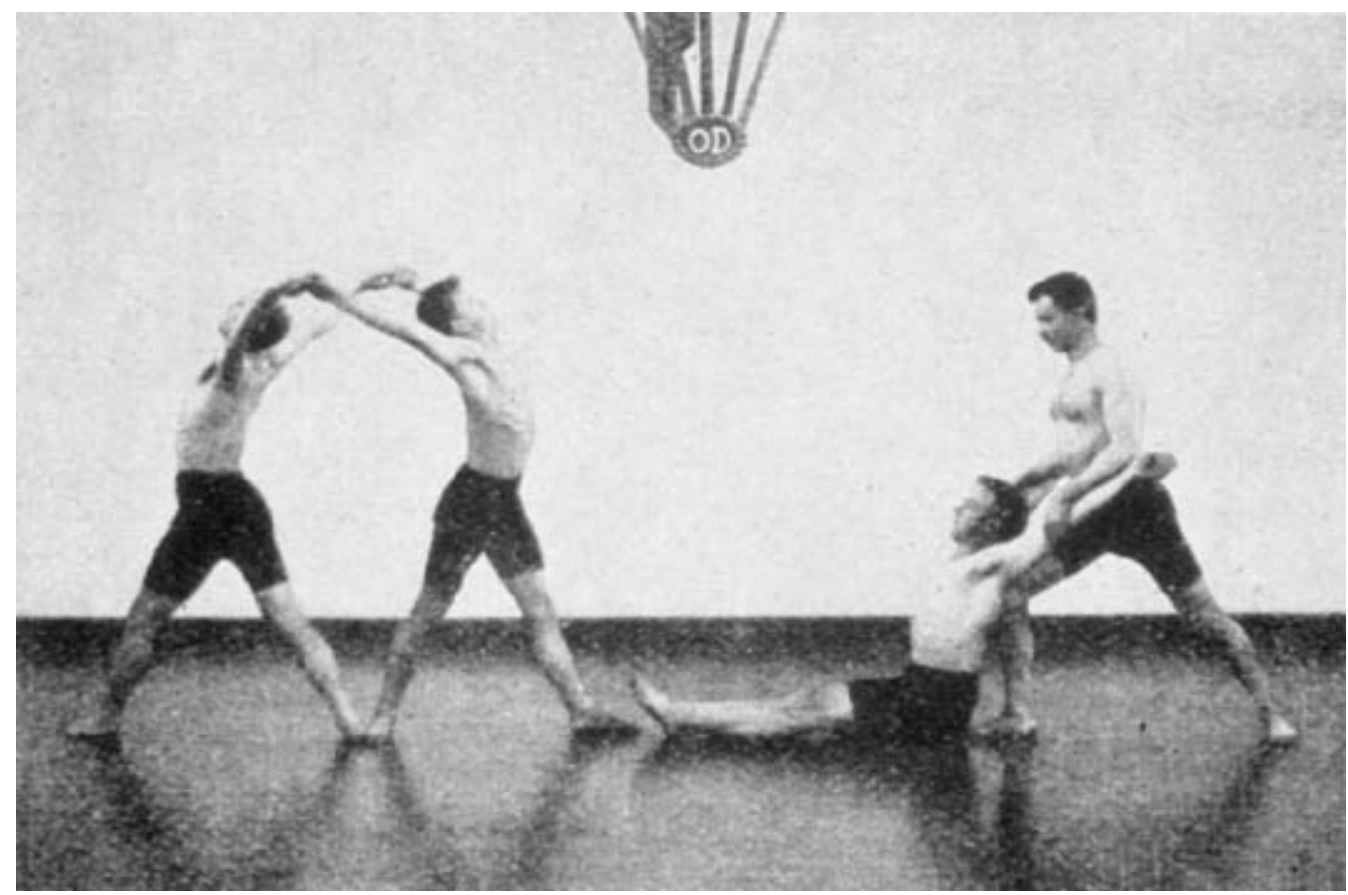

struktur i østrigsk skolegymnastik, hvilket var titlen på deres bog.

K. Gaulhofer og M. Streicher anførte 7 bøger skrevet af K.A. Knudsen, 5 offentliggjort på dansk. Bortset fra deres egne værker, så var K.A. Knudsen den forfatter, der oftest blev refereret til. Niels Bukh's tyske oversættelse af Grundgymnastik var blevet offentliggjort så sent som $1923,{ }^{39}$ og den blev der også refereret til i anden udgave.

K. Gaulhofer og M. Streicher introducerede dansk gymnastik lånt fra Niels Bukh, og de offentliggjorde også billeder af partnerøvelser, som man kan finde i Bukh's tyske oversættelse fra 1923.

Det ville dog være forkert at anklage $\mathrm{K}$. Gaulhofer og M. Streicher for bare at plagiere Niels Bukh, idet deres pædagogiske antagelser og samling af naturlige gymnastikøvelser var forskellig fra Bukhs. Ikke desto mindre var de to østrigere vigti- ge for assimilationen af dansk gymnastik i Tyskland fra 1924 og frem. ${ }^{40}$

I 1925 arbejdede man i Prøjsen ud fra et nyt gymnastikcurriculum for gymnasieskoler for drenge. ${ }^{41}$ Erich Harte, en varm fortaler for den østrigske skole, og Edmund Neuendorff, en konservativ repræsentant for den tyske gymnastikforening, var begge ansvarlige for strukturen og indholdet i dette nye gymnastikcurriculum.

Den tidligere Spiess-struktur med ordnede frie $\varnothing$ velser og redskabsøvelser blev fuldstændig erstattet af en ny tredelt struktur, kaldet »skoling af kroppen«, »konkurrencegymnastik « og »lege «. Formålet med »skolingen af kroppen« og samlingen af gymnastikøvelser med henblik på træning af kroppen var i virkeligheden identisk med Bukh's ide og hans samling af Grundgymnastik. For den konservative E. Neuendorff, som brugte begrebet kropsskole, var denne type gymnastik i virkelig- 


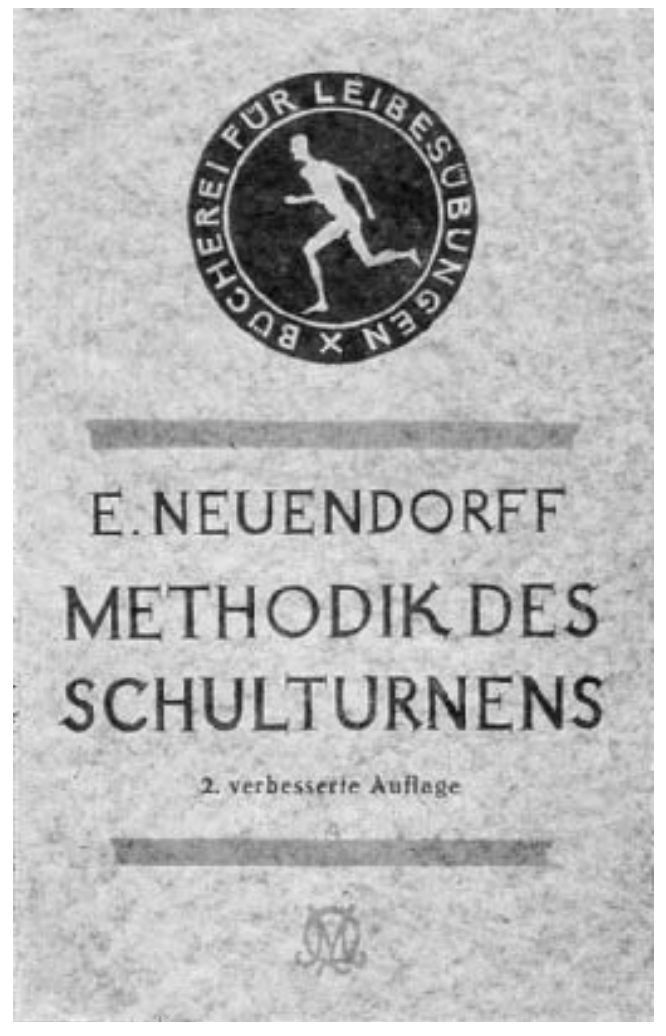

heden fundamental for det næste trin »konkurrencegymnastik «, der også inkluderede en mængde typiske danske gulvøvelser med håndstand osv.

I hans yndlingsbog om »Skolegymnastikmetoder « skrev E. Neuendorff senere et specielt kapitel om »skoling af kroppen«, og han inkluderede talrige billeder for at illustrere sin samling af kropsøvelser. ${ }^{42}$ Jeg har kun taget nogle få eksempler fra hans bog.

Når vi sammenligner de tidligere publicerede billeder, dokumenteret i den tyske oversættelse af Niels Bukh's håndbog, med billeder publiceret senere i E. Neuendorffs vejledning til det nye statslige gymnastikcurriculum, er der tydeligvis mange ligheder. Men Neuendorff vedkendte sig aldrig sine kilder i denne bog, og han anførte heller ikke nogen dansk oprindelse i sin referenceliste.

Han kopierede, i det mindste i denne vejledning til gymnastikpensum i de prøj-

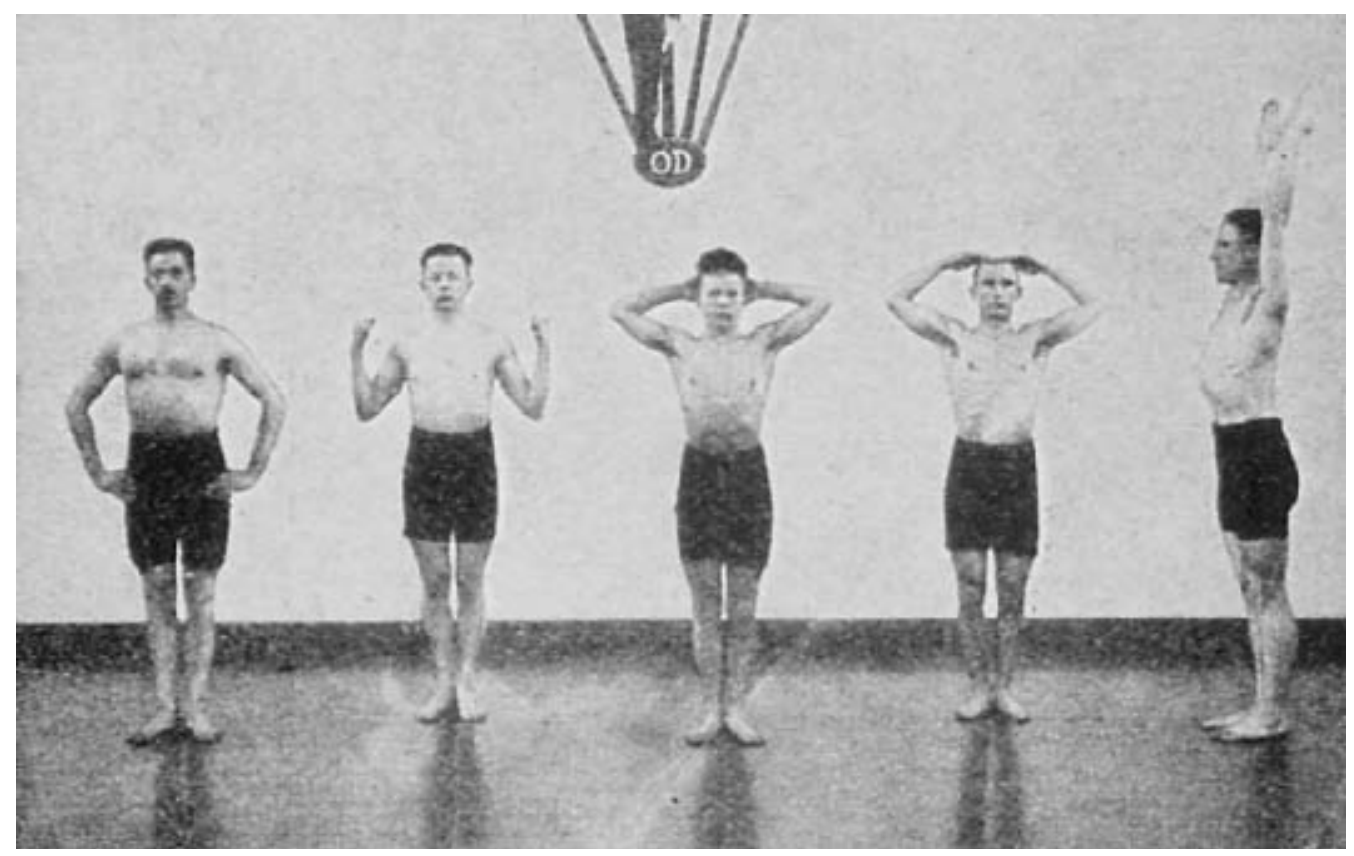



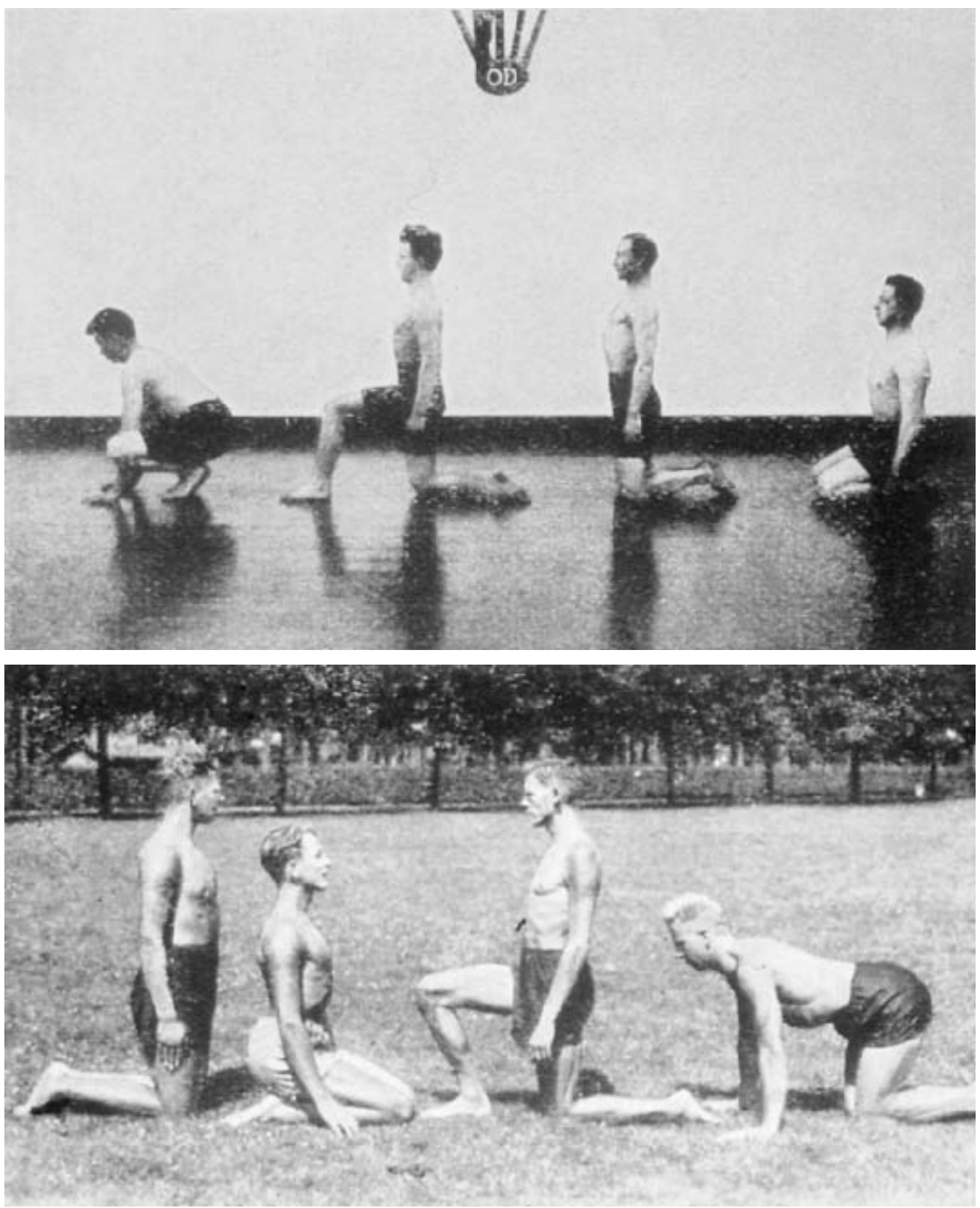

siske gymnasieskoler for drenge, dansk gymnastik, og gennemtvang implementeringen af denne i gymnastiktimerne.

I et tidligere forskningsprojekt rekonstruerede vi indholdet af en gymnastiktime i en gymnasieskole i Rhin-Ruhr området under Weimarrepublikken. Vi brugte publicerede skolerapporter og ikke-publiceret håndskrevet materiale gemt i skole- og byarkiver samt provinsarkiver, hvor sags- 
mapper tilhørende de ansvarlige regionale skolemyndigheder blev opbevaret.

Vores undersøgelse fokuserede på gymnasieskoler for drenge i byerne Düsseldorf, Krefeld, Duisburg og Essen. ${ }^{43}$

Vi fandt, at dansk gymnastik var blevet inkluderet $\mathrm{i}$ almindelig tysk gymnastikundervisning siden 1926, hvad angår fundamental gymnastik som en del af kropsskolen, særligt i de lavere klasser (5.-7. klasse).
Spørgsmålet er, hvad var årsagen til, at dansk gymnastik påvirkede tysk skolegymnastikundervisning så kraftigt i 1920'erne?

Reformgymnaster som E. Harte og andre, såvel som beskyttere af den tyske gymnastiktradition som E. Neuendorff, var berusede af den danske påvirkning, og på forskellig vis blev begge fortalere for dansk gymnastik, ikke kun i skolen. Selvfølgelig arbejdede Niels Bukh og hans elever i den samme retning, når de var i Tysk-

Tabel 3: Kropsskole i gymnastiktimer

\begin{tabular}{|c|c|c|}
\hline 5.-7. klasse & 8.-10. klasse & 11.-13. klasse \\
\hline $\begin{array}{l}\text { Gå/trin } \\
\text { (på tå/hæl) }\end{array}$ & Ordensøvelser & Ordens $\varnothing$ velser \\
\hline $\begin{array}{l}\text { Holdnings } \varnothing \text { velser } \\
\text { (efterligning af dyre- og } \\
\text { arbejdsbevægelser; sidde- } \\
\text { og ståøvelser, fremad og } \\
\text { sidebøjning, } \\
\text { balanceøvelser ribbe- } \\
\text { og træstavsøvelser }\end{array}$ & $\begin{array}{l}\text { Holdnings } \varnothing \text { velser } \\
\text { sidde- og ståøvelser, } \\
\text { balanceøvelser med } \\
\text { svensk bom, stige, } \\
\text { strækøvelser; } \\
\text { jernstavsøvelser }\end{array}$ & $\begin{array}{l}\text { Holdningsøvelser } \\
\text { (det samme som i 8.-10. } \\
\text { klasse; fremad horisontal } \\
\text { balance på et ben } \\
\text { torsoøvelser }\end{array}$ \\
\hline $\begin{array}{l}\mathrm{L} \phi \mathrm{b} \\
(50-2000 \mathrm{~m})\end{array}$ & $\begin{array}{l}\mathrm{L} \varnothing \mathrm{b} \\
(50-2000 \mathrm{~m})\end{array}$ & $\begin{array}{l}\mathrm{L} \varnothing \mathrm{b} \\
(50-3000 \mathrm{~m}, \text { hækkeløb, } \\
\text { orienteringsløb) }\end{array}$ \\
\hline
\end{tabular}

Tabel 4: Konkurrencegymnastik i gymnastiktimer

\begin{tabular}{|c|c|c|}
\hline 5.-7. klasse & 8.-10. klasse & 11.-13. klasse \\
\hline Atletik & Atletik & Atletik \\
\hline $\begin{array}{l}\text { Styrke- og } \\
\text { fleksibilitets } \emptyset \text { velser } \\
\text { (reb- og pælklatring, stige, } \\
\text { simpel horisontal og } \\
\text { parallel barre }\end{array}$ & $\begin{array}{l}\text { Styrke- og } \\
\text { fleksibilitets } \varnothing \text { velser } \\
\text { (klatring, svenske } \\
\text { murøvelser, horisontal } \\
\text { og parallel barre } \operatorname{lvelser} \\
\text { hest }\end{array}$ & $\begin{array}{l}\text { Styrke- og } \\
\text { fleksibilitetsøvelser } \\
\text { (det samme som i 8.-10. } \\
\text { klasse, vanskeligere } \\
\varnothing v e l s e r\end{array}$ \\
\hline $\begin{array}{l}\text { Gulvøvelser } \\
\text { forlæns rulle, } \\
\text { skubbekampe, terrænløb }\end{array}$ & $\begin{array}{l}\text { Gulvøvelser } \\
\text { (håndbalance, håndstand, } \\
\text { baglæns rulle, kraftspring }\end{array}$ & $\begin{array}{l}\text { Gulvøvelser } \\
\text { (samme som i 8.-10. } \\
\text { klasse, brydning) }\end{array}$ \\
\hline
\end{tabular}




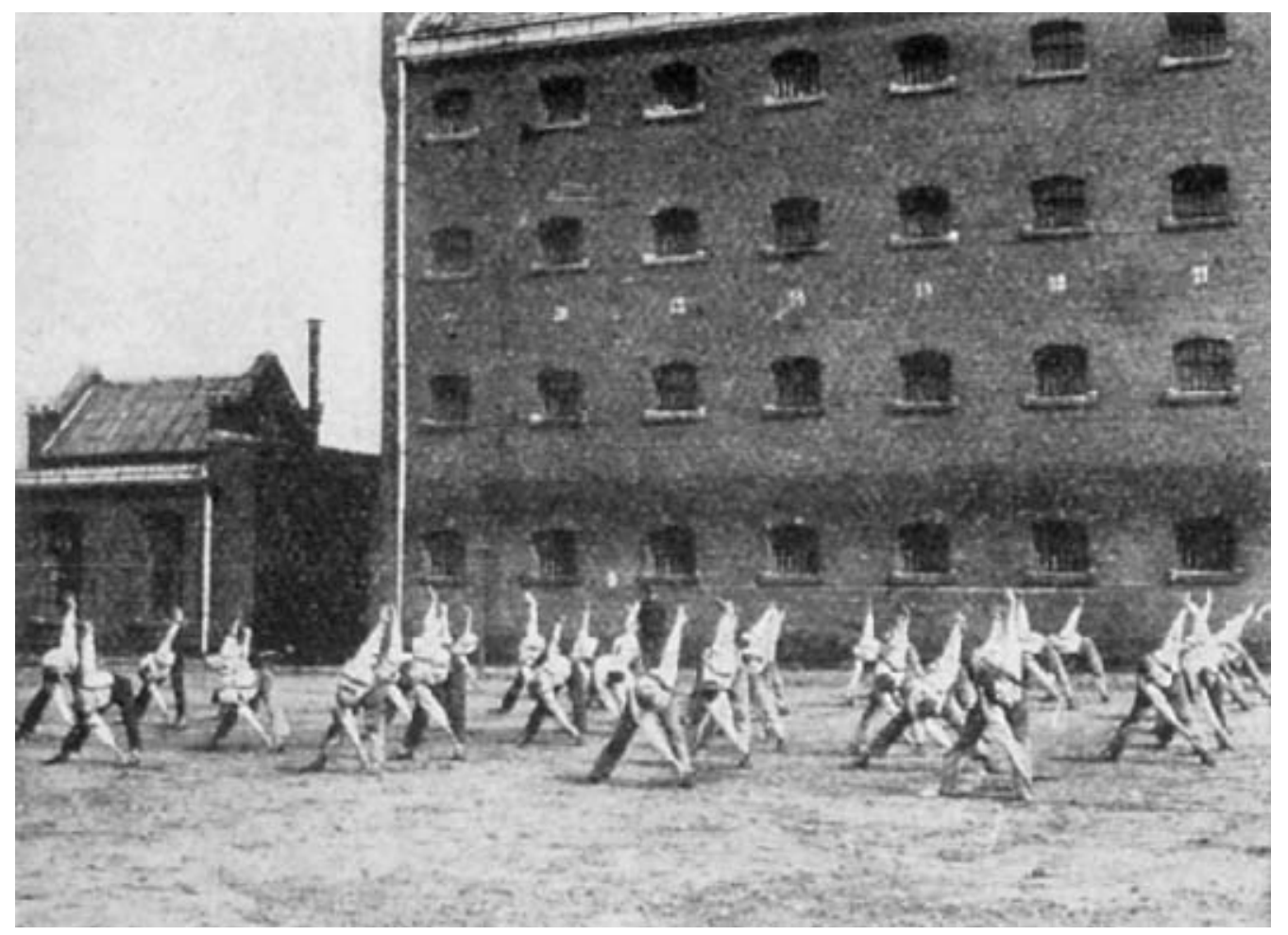

land i 1920'erne for at vise deres gymnastik; tilsvarende rejste mange tyskere til Ollerup og deltog i feriekurser, og kom senere med postive tilbagemeldinger om hvad de havde oplevet i Danmark. ${ }^{44}$

Tyske reformgymnaster bifaldt arten og udvalget af de gymnastiske $\varnothing$ velser, som faldt sammen med den naturlige gymnastiks uddannelsesmæssige formål. ${ }^{45}$ Konservative tyske gymnaster var imponerede over undervisningsmetoderne i den danske gymnastik. De beundrede den aerobe belastning under udførelse af øvelserne, den udtalte træning af fleksibilitet, og den hurtighed hvormed man kunne skifte fra én $\emptyset$ velse til den næste uden pause. ${ }^{46}$

Dette aspekt, det hurtige skift fra udførelsen af en opgave til udførelse af den næste med mellemliggende vippen på tæerne, blev godt modtaget og endda ka- rakteriseret i det tyske sprog med et specielt verbum, de kaldte det $\gg$ bukhen $\ll{ }^{47}$

Den måde man underviste i dansk gymnastik på var sportslig, sammenkædende konkurrenceånden med gymnastik. Træning af kroppen med grundgymnastik blev derfor en forudsætning for videre specialtræning i forskellige gymnastiske teknikker samt i atletikdisciplinerne. Det er derfor ikke overraskende, at Niels Bukh's gymnastik også blev en del af træningsprogrammet for de fremspirende atletikgrupper i tyske gymnastikklubber, lige som det blev praktiseret som gymnastik for fodboldspillere frem til 1960 'erne. ${ }^{48}$

Ikke kun fodboldspillere - hvis I erindrer, er jeg nu tilbage ved mit første emne men også fanger i tyske fængsler skulle udføre Bukh's gymnastik, hvilket til slut viser dens virkelige græsrodsstøtte i mit land. 


\section{Konklusion}

Jeg omtalte ikke den franske indflydelse i Danmark i 1850 'erne, som stimulerede pigernes gymnastikundervisning, ${ }^{49}$ og jeg nævnte heller ikke, at Danmark før og efter den Første Verdenskrig eksporterede gymnastik til Frankrig, hvor den naturlige gymnast Hebert blev en stor tilhænger. Der mangler sikkert også nogle kapitler om den europæiske dimension i dansk gymnastik i 1930'erne og senere. Men det har været mit $\varnothing$ nske at fremhæve den europæiske skillevej, som findes i Danmark fra den tidlige begyndelse af den moderne borgerlige gymnastikuddannelse. Danmark har været et land som assimilerede de meget innovative træk i europæisk gymnastik, og som et resultat af dette opbyggede Danmark deres eget gymnastiksystem, der blev overført og implementeret rundt omkring i Europa.

\section{Noter}

1. Jvf. Trangbæk, E.: Danish Gymnastics: What's so Danish about the Danes? I: International Journal of the History of Sport, vol. 13, Aug., 1996b. s. 203-214.

2. Se f.eks. Korsgaard, O.: Krop om Kroppen. Andelsbøndernes gymnastik mellem almuens leg og borgerskabets sport. Odense 1986; Bonde, H.: Mandighed og sport, Odense 1991; Cops $\varnothing$, S.: Skolegymnastikkens modernisering 1884-1913, København 1985; Hansen, J.: Politics and Gymnastics in a Frontier Area post-1848, i: International Journal of the History of Sport, vol. 14, 1997, s. 25.-46. Lyhne, K.H.: A Comparative Study of the Organizing Tendencies in Danish Society emphasizing the Organization of Sports, 1861-1896: The Paradigmatic Shift from German to Swedish Gymnastics, i: Müller, NN./Rühl, J.K. (eds.) Sport History. Official Report of the Olympic Scientific Congress 1984, Niedernhausen 1985, s. 449-456; Kayser Nielsen, N.: Sport und Bauernideologie in der dänischen Sportgeschichte, i: Stadion vol 19/20, 1993/94, s. 198-216.

3. Eichberg, H.: Body Culture and Democratic Nationalism: Popular Gymnastics' in Nineteenth-Century Denmark, i: International Journal of the History of Sport, vol. 12., 1995. s. 108-124.

4. Gutsmuths, J.C.F.: Gymnastik für die Jugend, Schnepfenthal 1793, Klappentext.

5. Hemmingsen, Ch.: Professor Fr. Nachtegall. Zum 150, Geburtstag des Schöpfers des Turnens in Dänemark, i: Die Leibesübungen vol. 47, 1928, s. 157-160.

6. Leonard, F.: A Guide to the History of Physical Education, Westport 1971 (3rd edition), s. 181.

7. Leonard, F.: op.cit. s. 148-157.

8. Gutsmuths, J.C.F.: Gymnastik für die Jugend, 1804 ( $2^{\text {nd }}$ edition), s. 2; (Reprint of 1970, Limpert Publishing House).

9. Leonard, F.: op.cit. s. 182.

10. Leonard, F.: op.cit. s. 183.

11. Leonard, F.: op.cit. s. 185.

12. Se også Naul, R.: Physical Education Teacher Training. Historical Perspectives, i: Mester, J. (ed.) Sport Sciences in Europe 1993, Aachen 1993, s. 588-610.

13. Trangbæk, E.: »The Art of Soaring «-Acrobatics, Science, and Dreams, i: Pfister, G./Niewerth, T./Steins, G. (Hrsg.) Spiele der Welt im Spannungsfeld von Tradition und Moderne. Part 1, Berlin 1996a, s. 342-346.

14. Leonard, F.: op.cit. s. 187.

15. Eichberg, H.: op.cit. 1995, s. 111.

16. For yderligere oplysninger se Grossbröhmer, R., Winkelmann, J.: Das Stabturnen zwischen Reduktion und Kompensation der Leibesübungen im Turnunterricht, i: Naul, R. (Hrsg.) Körperlichkeit und Schulturnen im Kaiserreich, Wuppertal 1985, s. $145-162$

17. Meinander, H.: Towards a Bourgois Manhood, Helsinki 1994, s. 173.

18. Trangbæk, E. 1996a; Eichberg 1995.

19. Leonard, F.: op.cit. s. 189; Meinander, H.: op.cit. s. 108

20. For yderligere oplysninger om Tyskland se: Grossbröhmer, R.: Die Geschichte der preussischen Turnlehrer. Aachen 1994, s. 114; Naul, R./Grossbröhmer, R.: Carl Euler. Pionier der Turnlehrerbildung und Historiker des Schulturnens, i: Stadion vol. 15, 1989, s. 265-271.

21. Meinander, H.: op.cit. s. 109. 
22. Meinander, H.: op.cit. s. 22.

23. Meinander, H.: op.cit. s. 169.

24. Meinander, H.: op.cit. s. 141.

25. Trangbæk, E.: Mellem leg og disciplin. Gymnastikken i Danmark i 1800 tallet. Aabybro 1987, s. 12; Meinander, H.: op.cit. s. 169.

26. Leonard, F.: op.cit. s. 194.

27. ibid.

28. Borup-Nielsen, G.: An Historic Danish-British Connection: Junker's Gymnastic Institute at Silkeborg, Jutland, Denmark, i: International Journal of the History of Sport, vol. 10, 1993, s. 428-435. Se også Idrætshistorisk Årbog 1990 s. 91-96.

29. Borup-Nielsen, B.: op.cit. s. 431.

30. Leonard, F.: op.cit. s. 194.

31. Se hertil bl.a. Klara Aalbæk Korsgaard: Anna og Jørgine. 1996.

32. Schmidt, F.A.: Die Gymnastik an den schwedischen Volksschulen. Berlin 1909 ( $2^{\text {nd }}$ edition); Schmidt, F.A.: Die schwedische Schulgymnastik. Berlin 1912.

33. Kunsterziehung: Ergebnisse und Anregungen des dritten Kunsterziehungstages in Hamburg. Leipzig 1906.

34. Diebow, P.: Die schwedische Gymnastik nach Ziel, Stoff und Betrieb im Vergleich mit dem deutschen Turnen, i: Monatsschrift für das Turnwesen vol. 26, 1907, s. 33-41.

35. Törngren, L.: Lehrbuch der schwedischen Gymnastik. Esslingen 1908.

36. Leitfaden, das Knabenturnen in den Volksschulen ohne Turnhalle. Berlin 1909.

37. Knudsen, K.A.: Turnerische übungslehre. Leipzig 1915.

38. Gaulhofer, K./Streicher, M.: Grundzüge des österreichischen Schulturnens. Wien/Leipzig/New York 1924 ( $2^{\text {nd }}$ edition).

39. Bukh, N.: Grundgymnastik. Leipzig 1923.

40. Naul, R./Jonischeit, L.: Spuren des natürlichen Turnens in Deutschland, i: Grössing, St. (red.)
Margarete Streicher - Ein Leben für die Leibeserziehung, Salzburg 1991, s. 46-85.

41. Richtlinien für die Lehrpläne an höheren Schulen Preussens, i: Schütz, W.: Der Unterricht in den Leibesübungen an Schulen und Hochschulen. Teil 1. Berlin 1926, s. 50-64; Gessman, R.: Die amtlichen Richtlinien für da Schulturnen in Pressen zur Zeit der Weimarer Republik, i: Gessmann, R. (Hrsg.) Schulische Leibesübungen zur Zeit der Weimarer Republik, Köln 1987, s. 140-146.

42. Neuendorff, E.: Methodik des Schulturnens. Leipzig 1928 ( $2^{\text {nd }}$ edition $)$, s. 72-93.

43. For yderligere oplysning se: Naul, R.: Von Postsdam nach Weimar - Schulsportwirklichkeit zwischen pädagogischer Reform und politischer Indienstnahme, i: John, H.G./Naul, R. (Hrsg.) Jugendsport im ersten Drittel des 20. Jahrhunderts. Clausthal-Zellerfeld 1988, s. 106-120.

44. Se f.eks. Anna Siewers entusiastiske beretning i forordet til Bukhs tyske oversættelse i: »Fundamental Gymnastik«, i: Bukh, N. Grundgymnastik. Berlin 1923, s. V.

45. Harte, E.: Das nordische Turnen im Lichte der Entwicklung der Leibesübungen in Deutschland, i: Die Leibesübungen vol. 47, 1928, 1.139-143; Gaulhofer, K.: Schwedische Gymnastik und Österreichisches Schulturnen, i: Die Leibesübungen vol. 45, 1926, s. 531-535.

46. Neuendorff, E.: op.cit. s. 73.

47. Mehl, E.: Zur Würdigung von Niels Bukh, i: Die Leibesübungen vol. 1928, s. 156.

48. Silfverstrand, C./Rasmussen, M.: Illustriertes Lehrbuch der Leichtathletik, München 1925, s. 9; Peltzer, O.: Das Trainingsbuch des Leichtathleten, Stuttgart 1926 (4 (th $^{\text {edition}), ~ s . ~ 37: ~ A b r a h a m, ~ A .: ~}$ Sportliche Gymnastik, Leipzig, s. 37.

49. Trangbæk, E.: Woman, Body and Sport in Denmark at the End of $19^{\text {th }}$ Century, i: Stadion Vol 19/20 1993/94, s. 239-258. 